\title{
Physiological, Morphological, Phenological and Yield Evaluation of Durum Wheat Lines Under Rainfed Conditions
}

\author{
Merve Bayhan (Corresponding author) \\ Dicle University, Faculty of Agriculture, Department of Field Crops, \\ Diyarbakir, Turkey \\ E-mail: mervebayhan21@gmail.com \\ Remzi Ozkan \\ Dicle University, Faculty of Agriculture, Department of Field Crops, \\ Diyarbakır, Turkey \\ E-mail: rmziozkan@gmail.com \\ Irfan Ozberk \\ Harran University, Faculty of Agriculture, Department of Field Crops, \\ Sanliurfa, Turkey \\ E-mail: ozberki@harran.edu.tr
}

\begin{abstract}
Food products of durum wheat play an important role in the world trade because it can be grown only in certain and limited regions of the world. The study aimed to assess some agronomic characteristics of 120 advanced durum wheat lines obtained from CIMMYT (The International Maize and Wheat Improvement Center), ICARDA (International Center for Agricultural Research in the Dry Areas), APUTAEM (GAP International Agricultural Research and Training Center) and five control varieties (Artuklu, Eyyubi, Güneyyıldızı, Şahinbey and Zenit). Field trial was carried out in the experimental field of GAP International Agricultural Research Institute at Diyarbakır, Turkey, in 2015 - 2016 growing season. Experiment was conducted via augmented experimental design consisting of six blocks which has twenty five plots with five controls. The examined traits was traits was divided into groups at physiological (canopy temperature, flag leaf chlorophyll content, leaf area index at anthesis, grain filling duration and grain filling rate), phenological (plant emergence time, heading time, anthesis time and physiological maturity time), morphological (leaf glaucusness, leaf erectness, plant height and spike length) and yield - forming parameters (spike number, spikelet number, grain number, spike grain weight and grain yield). There was statistically significant difference between genotypes in all traits except canopy temperature. Correlation analysis showed a positive and significant correlation between yield and spike grain weight. As a result of the research, it was determined that 13 lines $(5,16,18,3,34,41,42$, 50, 52, 85, 92, 94 and 114) showing superior features than control cultivar in terms of different characteristics was selected and transferred to the advanced stages of breeding studies.
\end{abstract}

Keywords: Durum wheat, Yield, Augmented design, Diyarbakir

DOI: $10.7176 / \mathrm{JSTR} / 6-04-05$

\section{Introduction}

Wheat is one of the main nutritional sources in many countries and has a strategic role. Wheat meets a significant portion of the calories and protein required for human nutrition and is the basic food of approximately 40 countries covering $35 \%$ of the world's population (Kendal et al., 2012). Durum wheat, can be grown only in certain and limited regions of the world. For this reason, durum wheat is one of the products that play an important role in world trade and find buyers at high prices. World wheat production is around 744.6 million tons and it is thought that 40.7 million tons of wheat production belongs to durum wheat (IGC, 2017). Approximately $20 \%$ of world production of durum wheat is met by Turkey, including in the Middle East countries.

31 | $\mathrm{P}$ a g e

www.iiste.org 
Wheat breeding process, which requires intensive labor and long years, depending the genetic mechanisms of the characters and the selection ability of the appropriate genotypes. The Augmented experimental design (only the repetition of standards) is used to compare too many lines in one trial. In this experimental design, while the control varieties are repeated in each block, the advanced lines included in the experiment are located in the blocks without repeating. There are many research results on the existence of new selection techniques in wheat that show which biotechnology and physiology are complementary to traditional breeding programs (Reynolds et al., 2000). Physiologists and plant breeders suggested using physiological and / or morphological traits instead of yield per plant when selecting a single plant for yield potential in early generations. The main purpose of many plant breeders is to increase yields. This will be possible by selecting more efficient lines and varieties which result from morphological and physiological characteristics as well as disease resistance (Erkul \& Ünay, 2009).

Breeders develop new varieties with high yield power and bring them into production and carry out more comprehensive studies in breeding programs. However, despite all the studies, researches on physiological parameters in wheat breeding programs are still insufficient (Karaman, 2013).

In this study, it was aimed to reveal the variation in terms of physiological, phenological and morphological variations among advanced durum wheat lines and to adapt for Diyarbakir conditions and to determine the usability of these characteristics as selection criteria.

\section{Material and Methods}

This research was conducted in the experimental field of Diyarbakır GAP International Agricultural Research and Training Center during the 2015 - 2016 growing season. In this research, 120 winter durum wheat lines obtained from IDSN (International Durum Segregation Nursery) sets from CIMMYT (The International Maize and Wheat Improvement Center), IDON (International Durum Observation Nursery) sets from ICARDA (International Center for Agricultural Research in the Dry Areas) and GAPUTAEM (Diyarbakır GAP International Agricultural Research and Training Center) was used as plant material. In addition, widely planted in the region Sarıçanak - 98, Zenit, Artuklu, Eyyubi and Güneyyıldızı varieties was used control varieties (Table 1).

Table 1. Advanced durum wheat lines and control varieties used at the research

\begin{tabular}{|c|c|c|c|c|c|}
\hline Line No & Origin & Line No & Origin & Line No & Origin \\
\hline 1 & MN 2014-156 & 43 & 37th IDON 141 & 85 & IDSN $2014-1572$ \\
\hline 2 & MN $2014-1511$ & 44 & 37th IDON 144 & 86 & IDSN $2014-1577$ \\
\hline 3 & MN $2014-1512$ & 45 & IDSN $2014-156$ & 87 & IDSN $2014-1580$ \\
\hline 4 & MN 2014-1521 & 46 & IDSN $2014-157$ & 88 & IDSN $2014-1584$ \\
\hline 5 & MN $2014-1523$ & 47 & IDSN $2014-158$ & 89 & IDSN $2014-1590$ \\
\hline 6 & MN $2014-1530$ & 48 & IDSN $2014-159$ & 90 & IDSN $2014-1593$ \\
\hline 7 & MN $2014-1532$ & 49 & IDSN $2014-1510$ & 91 & IDSN $2014-1595$ \\
\hline 8 & MN $2014-1533$ & 50 & IDSN $2014-1511$ & 92 & IDSN $2014-1596$ \\
\hline 9 & MN 2014 - 1535 & 51 & IDSN $2014-1512$ & 93 & IDSN $2014-1597$ \\
\hline 10 & MN $2014-1538$ & 52 & IDSN $2014-1513$ & 94 & IDSN $2014-1598$ \\
\hline 11 & MN $2014-1539$ & 53 & IDSN $2014-1514$ & 95 & IDSN $2014-1599$ \\
\hline 12 & MN 2014-15 41 & 54 & IDSN $2014-1515$ & 96 & IDSN $2014-15100$ \\
\hline 13 & MN $2014-1547$ & 55 & IDSN $2014-1518$ & 97 & IDSN $2014-15102$ \\
\hline 14 & MN $2014-1548$ & 56 & IDSN $2014-1522$ & 98 & IDSN $2014-15104$ \\
\hline 15 & MN $2014-1555$ & 57 & IDSN $2014-1523$ & 99 & IDSN $2014-15112$ \\
\hline 16 & MN $2014-1561$ & 58 & IDSN $2014-1527$ & 100 & IDSN $2014-15114$ \\
\hline 17 & MN $2014-1563$ & 59 & IDSN $2014-1534$ & 101 & IDSN $2014-15134$ \\
\hline 18 & MN $2014-1564$ & 60 & IDSN $2014-1536$ & 102 & IDSN $2014-15140$ \\
\hline 19 & MN $2014-1566$ & 61 & IDSN $2014-1537$ & 103 & IDSN $2014-15148$ \\
\hline 20 & MN $2014-1567$ & 62 & IDSN $2014-1538$ & 104 & IDSN $2014-15149$ \\
\hline 21 & 37 th IDON 4 & 63 & IDSN $2014-1539$ & 105 & IDSN $2014-15150$ \\
\hline 22 & 37 th IDON 6 & 64 & IDSN $2014-1540$ & 106 & IDSN $2014-15151$ \\
\hline 23 & 37 th IDON 10 & 65 & IDSN $2014-1541$ & 107 & IDSN $2014-15152$ \\
\hline 24 & 37th IDON 12 & 66 & IDSN $2014-1542$ & 108 & IDSN $2014-15153$ \\
\hline 25 & 37 th IDON 15 & 67 & IDSN $2014-1543$ & 109 & IDSN $2014-15154$ \\
\hline 26 & 37th IDON 17 & 68 & IDSN $2014-1544$ & 110 & IDSN $2014-15156$ \\
\hline
\end{tabular}

32 | P a g e www.iiste.org 


\begin{tabular}{|c|c|c|c|c|c|}
\hline \multicolumn{6}{|c|}{ Table 1. Continue } \\
\hline 27 & 37th IDON 19 & 69 & IDSN $2014-1545$ & 111 & IDSN $2014-15163$ \\
\hline 28 & 37 th IDON 22 & 70 & IDSN $2014-1546$ & 112 & IDSN $2014-15180$ \\
\hline 29 & 37 th IDON 24 & 71 & IDSN $2014-1547$ & 113 & IDSN $2014-15188$ \\
\hline 30 & 37 th IDON 29 & 72 & IDSN $2014-1548$ & 114 & IDSN $2014-15196$ \\
\hline 31 & 37th IDON 34 & 73 & IDSN $2014-1549$ & 115 & IDSN $2014-15197$ \\
\hline 32 & 37 th IDON 38 & 74 & IDSN $2014-1550$ & 116 & IDSN $2014-15199$ \\
\hline 33 & 37 th IDON 45 & 75 & IDSN $2014-1551$ & 117 & IDSN $2014-15201$ \\
\hline 34 & 37th IDON 51 & 76 & IDSN $2014-1552$ & 118 & IDSN $2014-15210$ \\
\hline 35 & 37 th IDON 54 & 77 & IDSN $2014-1553$ & 119 & IDSN $2014-15214$ \\
\hline 36 & 37 th IDON 56 & 78 & IDSN $2014-1554$ & 120 & IDSN $2014-15218$ \\
\hline 37 & 37 th IDON 85 & 79 & IDSN $2014-1555$ & 121 & Artuklu (control) \\
\hline 38 & 37 th IDON 89 & 80 & IDSN $2014-1564$ & 122 & Eyyubi (control) \\
\hline 39 & 37th IDON 91 & 81 & IDSN $2014-1565$ & 123 & Güney Yıldızı (control) \\
\hline 40 & 37th IDON 106 & 82 & IDSN $2014-1566$ & 124 & Sarıçanak - 98 (control) \\
\hline 41 & 37th IDON 135 & 83 & IDSN $2014-1567$ & 125 & Zenit (control) \\
\hline 42 & 37th IDON 139 & 84 & IDSN $2014-1569$ & & \\
\hline
\end{tabular}

The experiment was sowed on 17.10.2015 date according to the Augmented experimental design in 6 blocks each consisting of 25 plots (Petersen, 1985). In this way 20 different new lines in each block and 5 control varieties (with a degree of freedom of error $>10$ ) of the experiment consisted of a total of 150 plots. While the control varieties was repeated in each block as a basis for the calculation of the test error, the wheat lines included in the experiment was distributed to the blocks sequentially. The sowing process was carried out on standard agricultural practice (seedbed preparation included mouldboard plough, disc harrow and cultivator) with 6 rows of plot seeder and 500 grain / $\mathrm{m} 2$ planting density. Experiment was carried out by the standard technology of scientific farming production of wheat. The plots was formed as $7.2 \mathrm{~m}^{2}$ (6 rows $\times 0.2 \mathrm{~m}$ inter-row $\times 6 \mathrm{~m}$ length) in sowing and $6 \mathrm{~m}^{2}(6$ rows $\times 0.2 \mathrm{~m}$ inter - row $\times 5 \mathrm{~m}$ length) in harvest. In the experiment, $8 \mathrm{~N}(\mathrm{~kg} / \mathrm{da})+8 \mathrm{P} 2 \mathrm{O} 5(\mathrm{~kg} / \mathrm{da})$ was used as base fertilizer during sowing and $6 \mathrm{~N}(\mathrm{~kg} / \mathrm{da})$ was used as top fertilizer on tillering stage (Aktan et. all., 1980). Since the wheat growing season was dry, the plant was irrigated to the field capacity once during the milk development stage. As there are dense weeds in the experiment area, chemical control was carried out once during the period when weeds had $2-4$ leaves in order to provide weed control. Fenoxaprop $-\mathrm{P}-$ Ethyl was used for narrow - leaved weeds and Tribenuron - Methyl chemical drugs was used for broad - leaved weeds. Since disease and insect pests was not encountered in the experiment area, chemical drugs was not used. The harvesting process was carried out on 15 June 2016 with the Hege 140 plot harvester.

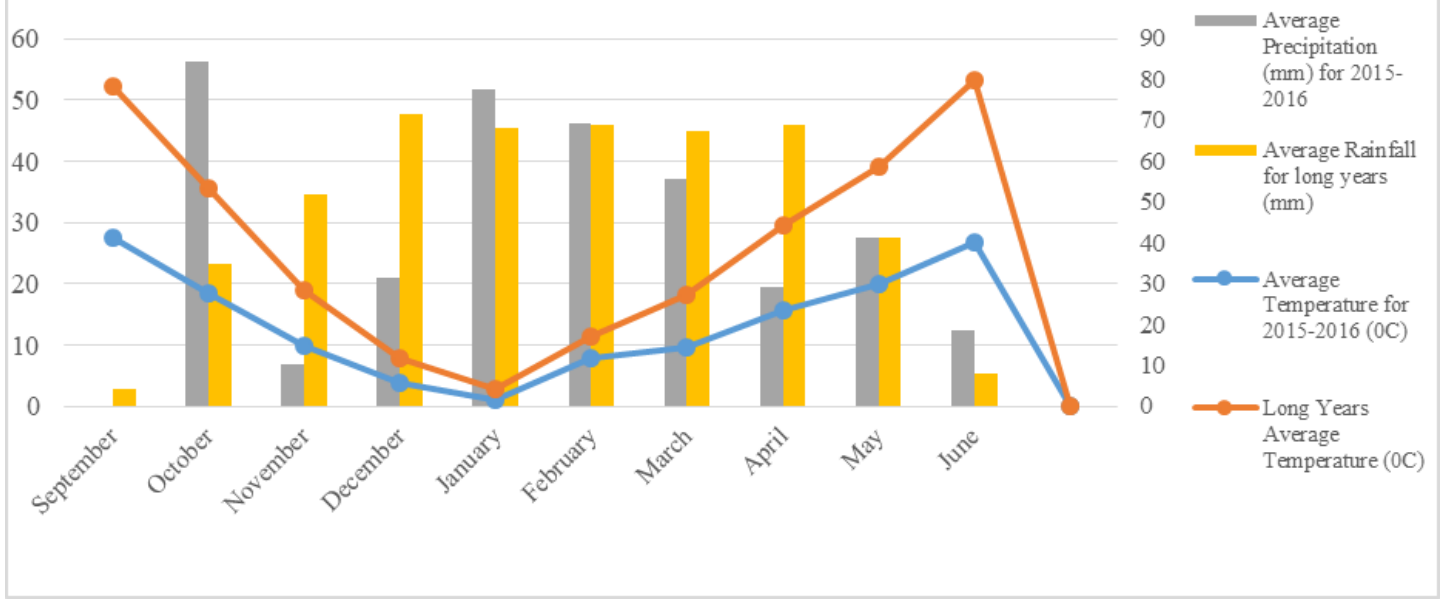

Figure 1 The climate data represent wheat growing period both long years and 2015 - 2016 years (Turkish State Meteorological Service, 2016) 
The area where research was carried out is located in Diyarbakır, Southeast Anatolia climate region with an altitude of $630 \mathrm{~m}$ and an average rainfall of $475 \mathrm{~mm}$ for long years $(1927-2015)$. The region has a harsh continental climate and a semi - arid highland climate. Summers are very hot, dry and long, winters are cold and rainy. The climate data represent wheat growing period both long years and $2015-2016$ years are given in Figure 1. In the 2015 - 2016 cultivation season, Diyarbakır province, which is experiment field, received $417 \mathrm{~mm}$ precipitation by staying behind $484 \mathrm{~mm}$ which is the average rainfall for long years. According to the trial year climate data, the highest rainfall occurs in October, January and February. January average temperature is $1.1^{\circ} \mathrm{C}$, the lowest temperature average of the year, while the average monthly temperature in April and May was higher than the average temperature for long years. The difference in precipitation between the driest month and the wettest month was $77 \mathrm{~mm}$. For long years, the average temperature was $24.8^{\circ} \mathrm{C}$ (Turkish State Meteorological Service, 2016).

Soil samples taken from experiment was analyzed in the Laboratory of Southeastern Anatolia Agricultural Research Institute. According to the results of the analysis (Bouyoucos, 1951) the soil properties of the experiment field was clayey - loam and medium alkaline and the rate of organic matter was low (Table 2).

Table 2. Soil properties of the experimental field

\begin{tabular}{ccccccc}
\hline $\begin{array}{c}\text { Class } \\
\text { Structure }\end{array}$ & $\begin{array}{c}\text { Total } \\
\text { Salt } \\
(\boldsymbol{\%})\end{array}$ & $\mathbf{p H}$ & $\begin{array}{c}\text { Lime } \\
\mathbf{( \% )}\end{array}$ & $\begin{array}{c}\text { Phosphorus } \\
(\mathbf{k g} / \mathbf{d a})\end{array}$ & $\begin{array}{c}\text { Organic } \\
\text { Matter }(\boldsymbol{\%})\end{array}$ & $\begin{array}{c}\text { Saturation with } \\
\text { water } \\
(\boldsymbol{\%})\end{array}$ \\
\hline $\begin{array}{c}\text { Clayey - } \\
\text { Loamy Soil }\end{array}$ & 0.08 & 7.95 & 13.13 & 2.36 & 0.45 & 63 \\
\hline
\end{tabular}

\subsection{Data acquisition and evaluation}

Physiological characteristics: The canopy temperature was derived from infrared (IR) radiometer measurements (in 2010 \& 2011: SI 111 \& SI 211 sensors, Apogee Instruments, Logan, USA; in 2013 \& 2014: IR120 sensors, Campbell Scientific, Logan, UT, USA). The sensors were placed $0.5 \mathrm{~m}$ above the canopy using a nadir-viewing angle (Neukam et al., 2015). Note that the position of the sensors was shifted at regular intervals to account for changes in the canopy height. Flag leaf chlorophyll content made three times during heading, anthesis and milk development stage and measured by SPAD 502 chlorophyll meter (SPAD-502, Minolta, Japan). Ten plants per treatment were selected randomly and SPAD values were recorded from the fully matured leaves counted from the top of the plants, the youngest fully expanded leaf.

Leaf area index at anthesis (LAI2000 plant canopy analyzer, Li-Cor Inc., Lincoln, NE, USA), grain filling duration (days), grain filling rate ( $\mathrm{mg} /$ day), phenological characteristics; plant emergence time (day), heading time (day), anthesis time (day), physiological maturity time (day), morphological characteristics; flag leaf glaucusness $\left(1-5\right.$ scale), leaf erectness $\left(0-90^{\circ}\right)$, plant height $(\mathrm{cm})$, spike length $(\mathrm{cm})$ yield and yield components; spike number $\left(\right.$ spike $\left./ \mathrm{m}^{2}\right)$, spikelet number (number), spike grain number (number), spike grain weight (g) and grain yield ( $\mathrm{kg} / \mathrm{da}$ ) was investigated. All physiological parameters was measured periodically between 11:00 - 14:00 in the absence of wind in the heading time.

Augmented variance analysis was based on randomized blocks experiment design consisting of 5 variety $\times 6$ blocks. The values of the control varieties are carried out analysis of variance. The value of the highest standard variety or the value of the lowest standard variety was determined for the characters examined. The LSI (Least significant increase) value was added to the values of the highest control varieties (value of standard variety + LSI) and subtracted from the lowest standard variety (value of standard variety LSI). Thus, the number of lines exceeding the standard variety was determined (Federer, $1961 \& 1975$ ). In Augmented designs the effect of each block is estimated by the formula: $r_{j}=1 / c\left(B_{j}-M\right)$,

where $c$ : is the number of controls, $B_{j}$ : is the sum of all controls in $\mathrm{j}$ block and $\mathrm{M}$ : is the sum of all means. The 5\% general LSD for comparing an adjusted selection yield with the mean yield of a control is calculated by the formula $L S D=t_{0,3} \sqrt{\mathrm{Svc2}} \mathrm{df}=$ is the block number-1.

The difference between an adjusted selection yield and a control mean is $\mathrm{Svc}^{2}=(\mathrm{b}-1)(\mathrm{c}-1) / \mathrm{bc}$, where $b$ : is the number of blocks and c: is the number of controls (Federer, $1961 \&$ 1975).

The data belong to observations and measurements was analysed using JMP 5.0 (SAS Institute Inc., US) package program according to augmented experiment design. 


\section{Results and Discussion}

\subsection{Physiological properties}

The difference between control varieties was found to be statistically significant according to the results of variance analysis related to canopy temperature, chlorophyll amounts, leaf area index, grain filling duration and grain filling rate characteristics. It is desirable that the temperature of the canopy measured by the Infrared Thermometer, which expresses the cooling ability of the plant, is low in the presence of temperature stress. Canopy temperature varies between $30.12-31.32{ }^{\circ} \mathrm{C}$ in the control varieties, while the highest canopy temperature 5 th line $\left(32.89^{\circ} \mathrm{C}\right)$, the lowest canopy temperature was obtained from 69 th line $\left(28.42^{\circ} \mathrm{C}\right)$. After adding the LSI value to the value of Zenit control variety having the highest canopy temperature value, the number of lines remaining above this value was 1 line and after subtracting LSI value from the value of Eyyubi control variety which has the lowest canopy temperature value, the number of lines remaining below this value was 5 lines. Tekdal (2012), in his research on the heat stress of durum wheat canopy temperature of milk development stage of varieties reported that a significant difference between the varieties. In the study of Y1ldirım et al. (2018) reported that the low canopy temperature is an indicator of the drought resistance of plants.

The amount of chlorophyll measured by the SPAD meter is desirable to be high since it represents the total amount of chlorophyll in the leaf. It has been reported that this criterion has been used very much in recent years and it can be improved in yields by being included in breeding programs as selection criteria (Y1ldirım et al., 2009). In this study, the content of flag leaf chlorophyll was measured in 3 different plant development periods including heading, anthesis and milk development stage and in the analysis of variance for these three periods, the difference between the control varieties was found to be statistically significant. While the flag leaf chlorophyll content varied between $42.22-52.8$ in the heading period, the highest chlorophyll content was obtained from the 50th line (55.63) and the lowest chlorophyll content from the 31st line (40.55). During the anthesis period, the flag leaf chlorophyll content varies between 50.53 - 61.78 in the control varieties, while the highest chlorophyll content was obtained from the 85th line (65.01) and the lowest chlorophyll content was obtained from the 102nd line (47.33) (Table 3). While the flag leaf chlorophyll content varied between $47.58-60.33$ in the milk development stage, the highest chlorophyll content was obtained from 85th line (63.31) and the lowest chlorophyll content was obtained from 102nd line (41.83). In all three periods in which the flag leaf chlorophyll content was measured, the highest value was observed in the Eyyubi and the lowest value was observed in the Güneyyıldızı control variety. When the lines was compared with the control varieties, the number of lines above the Eyyubi control variety was found as 1 line during the heading, 3 lines during anthesis and 2 lines during milk development stage.

When the chlorophyll content of heading, anthesis and milk development stages was evaluated, it was observed that there was a stability and consistency among genotypes. In addition, chlorophyll content was found to have higher values as the phenological period progressed. Although the chlorophyll content of flag leaf varies according to the environment and varieties in the new generation Mexican bread wheat varieties, it was found to be related with both net photosynthesis rate and increase in yield in durum wheat (Fisher et al., 1998). Significant and positive relationships was found between grain yield and SPAD values in winter wheat in both heading (Bavec \& Bavec, 2001) and grain filling period (Jiang et al., 2004). Although SPAD (Rharrabti et al., 2001) and canopy temperature (Royo et al., 2002) measurements in wheat have been fully investigate in recent years, the availability of SPAD and canopy temperature in Turkish wheat genotypes has not yet been fully clarified with a limited number of studies (Y1ldirim, 2005).

While the leaf area index (LAI) value of anthesis period varies between $4.49-5.61$ in the control varieties, the highest leaf area index value was obtained from 34th line (7.19) and the lowest leaf area index value was obtained from 23 rd line (3.55). While the number of lines above the highest value of control varieties Eyyubi and Artuklu was found to be 10 lines, the number of lines below the lowest value of Güneyyıldızı control variety was found to be 3 lines. In an environment where other environmental conditions are not limited, plant production (source accumulation) is determined by the amount of light energy that the plant can use throughout its life. LAI, which differs according to plant species and variety, also changes during the period of plant development (Lawless et al., 2004). In a study conducted by Koç and Barutçular (2000), the value of leaf area index in wheat gradually increased after germination of the plant and this value increased in later periods. Leaf area index of the plant reaches its maximum value 2 -3 weeks before flowering and in later periods, leaf loss increases with the aging of the plant and as a result of this, the leaf area index value of the plant decreases gradually. Grain filling duration is one of the most important factors in grain development. Grain filling duration varies between $36.83-38.83$ days in the control varieties, while the longest grain filling duration was obtained from line 12nd (40.59 days), the shortest grain filling duration was obtained from line 94th (33.47 days). Four lines was higher

35 I P a g e 
than the best control variety (Artuklu), while 18 lines was below the lowest control variety (Eyyubi). Ganguli et al. (1997) shorten the grain filling duration of high temperatures occurring during the grain filling period. They stated that yield decreases occur as a result of the decrease of grain weight by $3-$ $5 \%$ for each degree increasing in temperature.

The grain filling rate varies significantly depending on the available leaf area, photosynthesis rate and photosynthesis time after pollination. At the end of the study, grain filling rate of control varieties varied between $1.32-1.48 \mathrm{mg} /$ day. The highest grain filling rate was obtained from line 34th (1.77), while the lowest grain filling rate was obtained from line $88 \mathrm{th}(0.87 \mathrm{mg} /$ day $)$. While the number of lines remaining above the highest control variety (Artuklu) was 7 lines, the number of lines that value below the lowest control variety (Zenit) was found to be 45 lines. In the study of Yildirim et al. (2009), significant differences was found between the varieties in terms of the grain filling rate calculated as the ratio of the single grain weight to the grain filling time.

Table 3. Analysis of variance and average values of the varieties belong to physiological characteristics and number of lines above and below control varieties according to LSI value

\begin{tabular}{|c|c|c|c|c|c|c|c|}
\hline $\begin{array}{l}\text { Control Varieties and } \\
\text { Advanced Durum Wheat } \\
\text { Lines }\end{array}$ & $\begin{array}{c}\text { Canopy } \\
\text { Temperature } \\
\left({ }^{\circ} \mathrm{C}\right)\end{array}$ & $\begin{array}{l}\text { SPAD - } 1 \\
\text { (Heading } \\
\text { Period) }\end{array}$ & $\begin{array}{l}\text { SPAD - } 2 \\
\text { (Anthesis } \\
\text { Period) }\end{array}$ & $\begin{array}{c}\text { SPAD - 3 } \\
\text { (Milk } \\
\text { Development } \\
\text { Stage) } \\
\end{array}$ & $\begin{array}{l}\text { Leaf Area } \\
\text { Index at } \\
\text { Anthesis }\end{array}$ & $\begin{array}{l}\text { Grain Filling } \\
\text { Duration } \\
\text { (days) }\end{array}$ & $\begin{array}{c}\text { Grain Filling } \\
\text { Rate } \\
\text { (mg/day) }\end{array}$ \\
\hline Artuklu & 30,81 & $49,07 \mathrm{~b}$ & $57,17 \mathrm{~b}$ & $54,95 \mathrm{~b}$ & $5,61 \mathrm{a}$ & $38,83 \mathrm{a}$ & $1,48 \mathrm{a}$ \\
\hline Eyyubi & 30,12 & $52,80 \mathrm{a}$ & $61,78 \mathrm{a}$ & $60,33 \mathrm{a}$ & $5,61 \mathrm{a}$ & $36,83 \mathrm{c}$ & $1,39 \mathrm{ab}$ \\
\hline Güneyyıldızı & 30,46 & $42,22 \mathrm{c}$ & $50,53 \mathrm{c}$ & $47,58 \mathrm{c}$ & $4,49 \mathrm{~b}$ & $37,83 \mathrm{~b}$ & $1,33 \mathrm{~b}$ \\
\hline Sarıçanak - 98 & 30,51 & $48,87 \mathrm{c}$ & $57,6 \mathrm{~b}$ & $55,28 \mathrm{~b}$ & $4,8 \mathrm{ab}$ & $37,83 \mathrm{~b}$ & $1,48 \mathrm{a}$ \\
\hline Zenit & 31,32 & $49,02 \mathrm{~b}$ & $57,65 \mathrm{~b}$ & $55,48 \mathrm{~b}$ & $4,73 \mathrm{~b}$ & $37,5 \mathrm{bc}$ & $1,32 \mathrm{~b}$ \\
\hline Average (Control Varieties) & 30,64 & 48,39 & 56,94 & 54,76 & 5,05 & 37,8 & 1,39 \\
\hline $\begin{array}{l}\mathrm{F} \text { (Between Control } \\
\text { Varieties) }\end{array}$ & 1,121 & $23,1 * *$ & $37,0 * *$ & $43,2 * *$ & $3,1 *$ & $5,8 * *$ & $5,6^{* *}$ \\
\hline CV $(\%)$ & 3,4 & 4,03 & 2,86 & 3,11 & 14,32 & 1,97 & 5,75 \\
\hline Highest Value Line & $32,89_{5}$ & 55,6350 & 65,0185 & $63,31_{85}$ & $7,19_{34}$ & $40,59_{12}$ & $1,77_{34}$ \\
\hline Lowest Value Line & 28,4269 & $40,55_{31}$ & 47,33102 & 41,83102 & 3,5523 & 33,4794 & 0,8788 \\
\hline Average (Lines) & 30,55 & 48,94 & 57,33 & 55,3 & 5,1 & 37,27 & 1,31 \\
\hline LSI Value & 1,25 & 2,33 & 1,95 & 2,03 & 0,85 & 0,87 & 0,09 \\
\hline $\begin{array}{l}\text { Number of Lines Over the } \\
\text { Highest Control Varieties }\end{array}$ & 1 & 1 & 3 & 2 & 10 & 4 & 7 \\
\hline $\begin{array}{l}\text { Number of Lines Below the } \\
\text { Lowest Control Varieties }\end{array}$ & 5 & 0 & 1 & 1 & 3 & 18 & 45 \\
\hline
\end{tabular}

\subsection{Phenological properties}

According to the results of variance analysis related to plant emergence time, heading time, anthesis time and physiological maturity time, statistically significant difference was found between control varieties. Plant emergence time in control varieties ranged between 13.83 - 15.83 days. The lowest plant emergence was obtained from line 114th (11.65 days), the highest plant emergence was obtained from line 46th (17.85 days). In addition, according to the LSI value, the numbers of lines above the highest control variety (Artuklu) was found to be 5 lines while the number of lines below the lowest control variety (Eyyubi) was found to be 20 lines.

Heading time values of the control varieties ranged between 110.5 - 114.0 days. Among the genotypes, the highest heading time was obtained from line 75th (115.29 day), while the lowest spike time was obtained from line 42nd (105.89 day). In addition, according to LSI value, there was no line above the highest control variety (Sarıçanak - 98), while the number of lines below the lowest control variety (Zenit) was 11 lines. Heading time is an important factor in determining grain filling duration as well as determining the degree of negative effects of environmental factors such as cold damage, drought and high temperature after heading. Kendal et al. (2012) stated that the average heading time of some durum wheat varieties was 109 days, in this study it was observed that the heading time of the varieties was 112 days and the average heading time of the lines was 111.69 days.

Anthesis time of the control varieties ranged between 113.5 - 117.0 days. The highest anthesis time was obtained from line 75th (119.32 days) and the lowest anthesis time was obtained from line 42nd (109.52 days). According to the LSI value, while the number of lines remaining above the highest control variety (Eyyubi) was 1 line, the number of lines below the lowest control variety (Güneyyıldızi) was 7 lines. The physiological maturity time of the control varieties ranged between $151.5-155.5$ days. The highest physiological maturity time was obtained from line 74th (157.88 days), while the lowest physiological

36 | P a g e 
maturity time was obtained from line 52nd (145.88 days). In addition, according to LSI value, there was no line above the highest control variety (Eyyubi), while 10 lines was found below the lowest grammar variety (Güneyyıldızı). In a study by Tekdal (2012), it determined the highest physiological maturity time in Ç-1252 (158.00 days) variety and the lowest value in Svevo (166.00 days) variety. The varieties that is early in terms of the time of heading in cereals are preferred, and when it is called earliness, the expressed that it mean more the time of heading, however, the short time of heading and physiological maturity is undesirable in terms of grain yield (Soylu \& Sade, 2000).

Table 4. Analysis of variance and values of the varieties belong to phenological properties examined and the number of lines above and below the standards varieties according to LSI value

\begin{tabular}{|c|c|c|c|c|}
\hline $\begin{array}{l}\text { Control Varieties and Advanced } \\
\text { Durum Wheat Lines }\end{array}$ & $\begin{array}{c}\text { Plant Emergence } \\
\text { Time } \\
\text { (days) }\end{array}$ & $\begin{array}{l}\text { Heading } \\
\text { Time } \\
\text { (days) }\end{array}$ & $\begin{array}{l}\text { Anthesis } \\
\text { Time } \\
\text { (days) }\end{array}$ & $\begin{array}{l}\text { Physiological } \\
\text { Maturity Time } \\
\text { (days) }\end{array}$ \\
\hline Artuklu & $15,83 \mathrm{a}$ & $112,2 \mathrm{abc}$ & $116,8 \mathrm{a}$ & $153,7 \mathrm{abc}$ \\
\hline Eyyubi & $13,83 \mathrm{~b}$ & $112,5 \mathrm{ab}$ & $117,0 \mathrm{a}$ & $155,5 \mathrm{a}$ \\
\hline Güneyyıldızı & $15,50 \mathrm{a}$ & $111,0 \mathrm{bc}$ & $113,5 \mathrm{c}$ & $151,5 \mathrm{c}$ \\
\hline Sarıçanak - 98 & $14,00 \mathrm{~b}$ & $114,0 \mathrm{a}$ & $116,0 \mathrm{ab}$ & $154,8 \mathrm{ab}$ \\
\hline Zenit & $13,83 \mathrm{~b}$ & $110,5 \mathrm{c}$ & $114,3 \mathrm{bc}$ & $152,5 \mathrm{bc}$ \\
\hline Average (Control Varieties) & 14,6 & 112 & 115,5 & 153,6 \\
\hline F (Between Control Varieties) & $5,1 * *$ & $4,6^{* *}$ & $6,0 * *$ & $3,9 *$ \\
\hline $\mathrm{CV}(\%)$ & 7,19 & 1,4 & 1,3 & 1,32 \\
\hline Highest Value Line & 17,8546 & 115,2975 & 119,3275 & 157,8874 \\
\hline Lowest Value Line & 11,65114 & 105,8942 & 109,5242 & 145,8852 \\
\hline Average (Lines) & 14,09 & 111,69 & 115,25 & 152,49 \\
\hline LSI Value & 1,27 & 1,85 & 1,83 & 2,43 \\
\hline $\begin{array}{l}\text { Number of Lines Over the Highest } \\
\text { Control Varieties }\end{array}$ & 5 & 0 & 1 & 0 \\
\hline $\begin{array}{l}\text { Number of Lines Below the Lowest } \\
\text { Control Varieties }\end{array}$ & 20 & 11 & 7 & 10 \\
\hline
\end{tabular}

\subsection{Morphological features}

According to the results of variance analysis related to leaf glaucousness, leaf erectness, plant height and spike length, significant differences was found between control varieties. Leaf glaucousness, which is associated with increased radiation reflection and water use efficiency in stressful conditions and decreased leaf temperature and transpiration, provides maximum benefit, especially in post - flowering stress conditions (Royo et al. 2005). Leaf glaucousness was evaluated according to $0-5$ scales, where " 0 " is no glaucousness and " 5 represents fully cover of leaves. Control varieties the leaf glaucousness value ranged between $1.2-3.0$. The highest leaf glaucousness value was obtained from line 92nd (4.66), while the lowest leaf glaucousness value was obtained from line 46th (0.23). According to LSI value, while the number of lines remaining above the highest control variety (Sariçanak - 98) was 4 lines, the line below the lowest control variety (Zenit) was not found. Leaf glaucousness prevents the plant from overloading radiation and thus provides resistance to high temperature stress.

Leaf erectness associated with light use efficiency and provides high benefit, especially in areas without water stress (Royo et al. 2005). In the control varieties, the leaf erectness value varied between $60-70^{\circ}$. While the highest leaf erectness value was obtained from line $42 \mathrm{nd}\left(87.040^{\circ}\right)$, the lowest leaf erectness value was obtained from line $112 \mathrm{nd}\left(48.040^{\circ}\right)$. In addition, according to LSI value, the number of lines remaining above the highest control variety (Eyyubi) was 21 lines, while the number of lines below the lowest control variety (Zenit) was found to be 15 lines. Tekdal (2012), has been reported that almost all durum wheat lines selected in terms of superior features had erectness leaf structure. This situation emphasized that the leaf erectness should be evaluated together with the physiological parameters mentioned in cases where selection criteria are considered.

Table 4 examined the plant height values of the control varieties showed a change between $80.83-99.6$ $\mathrm{cm}$. While the line with the longest plant height was obtained from line $4 \mathrm{st}(111.56 \mathrm{~cm})$, the line with the shortest plant height was line 85 th $(74.40 \mathrm{~cm})$. In addition, according to LSI value, while the number of lines remaining above the highest control variety (Eyyubi) was 2 lines, the line below the lowest control variety (Zenit) was not found. In previous studies on durum wheats, the researchers reported that plant height ranges was $76.8-82.1 \mathrm{~cm}$ (Rock et al. (2009) and $55-115 \mathrm{~cm}$ (Kahraman et al. 2008). Sakin et 
al. (2004) reported that genotypes with long plant may be suitable for arid conditions, insufficient areas when straw is used for animal feeding, whereas shorter plants would be more suitable for fertile soils. While the spike length value varies between $6.48-7.82 \mathrm{~cm}$ in the control varieties, the highest spike length value was obtained from line 18 th $(9.34 \mathrm{~cm})$ and the lowest spike length value was obtained from line 65 th $(5.46 \mathrm{~cm})$. In addition, according to LSI value, the number of lines above the highest control variety (Zenit) and below the lowest grammar variety (Eyyubi) was found to be 6 lines. Acer (2004), whose studied, yield and quality characteristics of some wheats, shows similarity with the results of our study in terms of detecting a significant difference in spike length between varieties. Both long spike length and sparsely arranged spikelets is desirable in cereals. As stated in the studies; there was a positive and significant relationship between grain yield and spike length as stated by Yildirım et al. (1996). In addition, the relationship between spike length and grain yield may vary according to the spikelets row in the spike (Kahraman, 2006).

\subsection{Yield and yield components}

According to variance analysis results for the difference between control varieties was found to be statistically significant on the spike number, spikelet number, spike grain number, spike grain weight and grain yield components. Spike number is strongly affected by agronomic practice. While the square in the spike number varies between $440-625 \mathrm{spike} / \mathrm{m}^{2}$ in the control varieties, highest the square in the spike number was btained from line $31 \mathrm{st}\left(771.90 \mathrm{spike} / \mathrm{m}^{2}\right)$ and the lowest square in the spike number was belong to 95 th line $\left(301.52 \mathrm{spike} / \mathrm{m}^{2}\right)$. In addition, according to LSI value, the number of lines remaining above the highest control variety (Zenit) was 3 lines, while the number of lines below the lowest control variety (Sarıçanak - 98) was found to be 6 lines (Table 5). The capacity of tillering in the plant and fertility, maintenance ability of tillers until the harvest can change according to genotypes and cause differences at spike number to be (Valerio et al., 2009). Different results obtained in previous studies on spike number can be attributed to the genetic structure of the varieties, the different ecological conditions in the years of research and the soil structure of the locations (Özdemir, 2011).

The spikelet number, spike grain number and weight are important elements that determine grain yield (Demir et al., 1999). In terms of spikelet number control varieties ranged between $17.53-20.3$, the highest number of spikelets 5th line (22.13), while the lowest spikelets number value was obtained from the number 45 th line (15.09). In addition, according to LSI value, while the number of lines remaining above the highest control variety (Zenit) was 2 lines, the number of lines below the lowest control variety (Artuklu) was 11 lines (Table 3.4). Kendal (2008), worked durum wheats found that the average spikelet number was 13 and 12,9 for Diyarbakir and Elazığ conditions, respectively. In the Diyarbakır location, spikelet number of Furat - 93 was 12.8 and spikelet number of Sarıçanak - 98 was 13.6, while in the Elazığ location, spikelet number of Fırat - 93 was 12.4 and spikelet number of Sarıçanak - 98 was 13.5. As seen in Table 5, spike grain number in the control varieties ranged between $24.5-28.8$. The highest number of grains was obtained from line 5th (45.13), while the lowest number of grains was obtained from line 45th (16.33). In addition, according to LSI value, the number of lines remaining above the highest control variety (Sarıçanak - 98) was 29 lines, while the number of lines below the lowest control variety (Artuklu) was found to be 8 lines (Table 5). In a study conducted in Kahramanmaraş province, the average spike grain number for durum wheat was found to be 44.6 (Turan, 2008). Toncin (2004), in his research, he reported that the maximum spike grain number was obtained from the main stem spike, while spike grain number in the tiller spikes is decreasing gradually. Kün (1988) reported that grain formation in the spike is directly related to fertilization, and that rainy or extreme heat adversely affects fertilization and low humidity and high temperature following fertilization increase the efficiency of the grain, and low temperatures around $1-2{ }^{\circ} \mathrm{C}$ during fertilization lead to infertility and significant reductions in grain construction.

When Table 5 was examined, spike grain weight control varieties ranged between $1.98-2.51 \mathrm{~g}$. In terms of spike grain weight, the line with the highest value was line 16 th $(3.26 \mathrm{~g})$ while the line with the lowest value was line $84 \mathrm{th}(1.15 \mathrm{~g})$. In addition, according to LSI value, the number of lines remaining above the highest control variety (Sarıçanak - 98) was 5 lines, while the number of lines below the lowest control variety (Zenit) was 11 lines (Table 3.4). Kahrıman (2007), in his study of bread wheat in Çanakkale province, he concluded that the difference between the varieties was significant in terms of spike grain weight and observed that the spike grain weight values of varieties ranged between $1.22-$ 2.51 g. Kahraman (2013) stated that stress conditions cause increases in grain filling rate in wheat. In addition, it is reported that the square in the spike numbers and spike grain number are reduced due to the rapid development of high temperatures.

Grain yield of durum wheat, which has an increasing economic importance all over the world, has lower compared to bread wheat. Therefore, low grain yield of durum wheat should be increased. The grain

38 | P a g e

www.iiste.org 
yield of the control varieties ranged between 563.9 - $708.9 \mathrm{~kg} / \mathrm{da}$. The highest grain yield value was obtained from line $18 \mathrm{th}(858.37 \mathrm{~kg} / \mathrm{da})$, while the lowest grain yield value was obtained from line 5 th $(352.87 \mathrm{~kg} / \mathrm{da})$. In addition, according to LSI value, the number of lines remaining above the highest control variety (Sarıçanak - 98) was found to be 12 lines while the number of lines below the lowest control variety (Zenit) was found to be 8 lines (Table 3.4 Hadjichristodoulou (1982), reported that wheat grain yield variations is strongly depend on the variety and location, $5-79 \%$ of this variation was belong to annual rainfall while, $61-93 \%$ of this variation stem from seasonal rainfall distribution and high rainfall during heading time had positive effects on grain yield. Grain yield results from the combined effects of environmental factors and genetic potential. Factors such as sowing time, distribution of rainfall during the year, maximum and minimum temperatures, nutrient supplementation, disease and pest presence are thought to determine yield potential (Mut et al. 2005).

Table 5. Analysis of variance and average values of varieties belong to yield and yield components examined and number of lines above and below standards according to LSI value

\begin{tabular}{|c|c|c|c|c|c|}
\hline $\begin{array}{l}\text { Control Varieties and Advanced } \\
\text { Durum Wheat Lines }\end{array}$ & $\begin{array}{l}\text { Spike Number } \\
\left(\text { plant } / \mathrm{m}^{2}\right)\end{array}$ & $\begin{array}{l}\text { Spikelet } \\
\text { Number } \\
\text { (number) }\end{array}$ & $\begin{array}{c}\text { Spike Grain } \\
\text { Number } \\
\text { (number) }\end{array}$ & $\begin{array}{c}\text { Spike Grain } \\
\text { Weight } \\
(\mathrm{g})\end{array}$ & $\begin{array}{l}\text { Grain } \\
\text { Yield } \\
(\mathrm{kg} / \mathrm{da})\end{array}$ \\
\hline Artuklu & $546,67 \mathrm{a}$ & $17,53 \mathrm{~b}$ & $24,5 \mathrm{~b}$ & $2,04 \mathrm{~b}$ & $581,6 \mathrm{~b}$ \\
\hline Eyyubi & $440,00 \mathrm{~b}$ & $17,90 \mathrm{~b}$ & $28,3 \mathrm{a}$ & $2,16 \mathrm{~b}$ & $683,5 \mathrm{a}$ \\
\hline Güneyyıldızı & $570,00 \mathrm{a}$ & $17,77 \mathrm{~b}$ & $27,4 \mathrm{ab}$ & $2,1 \mathrm{~b}$ & $600,8 \mathrm{~b}$ \\
\hline Sarıçanak - 98 & $440,00 \mathrm{~b}$ & $18,50 \mathrm{~b}$ & $28,8 \mathrm{a}$ & $2,51 \mathrm{a}$ & $708,9 \mathrm{a}$ \\
\hline Zenit & $625,00 \mathrm{a}$ & $20,30 \mathrm{a}$ & $24,9 \mathrm{~b}$ & $1,98 \mathrm{~b}$ & $563,9 \mathrm{~b}$ \\
\hline Average (Control Varieties) & 524,33 & 18,4 & 26,8 & 2,16 & 627,7 \\
\hline F (Between Control Varieties) & $6,2 * *$ & $11,6 * *$ & $3,0 *$ & $3,5^{*}$ & $11.5^{* *}$ \\
\hline $\mathrm{CV}(\%)$ & 15,32 & 4,37 & 10,3 & 12,5 & 7,4 \\
\hline Highest Value Line & $771,90_{31}$ & $22,13_{5}$ & 45,135 & 3,2616 & $858,37_{18}$ \\
\hline Lowest Value Line & 301,5295 & 15,0945 & 16,3345 & 1,1584 & 352,875 \\
\hline Average (Lines) & 519,63 & 18,22 & 28,66 & 2,16 & 631,52 \\
\hline LSI Value & 96,47 & 0,95 & 3,28 & 0,33 & 55,7 \\
\hline $\begin{array}{l}\text { Number of Lines Over the } \\
\text { Highest Control Varieties }\end{array}$ & 3 & 2 & 29 & 5 & 12 \\
\hline $\begin{array}{l}\text { Number of Lines Below the } \\
\text { Lowest Control Varieties }\end{array}$ & 6 & 11 & 8 & 11 & 8 \\
\hline
\end{tabular}

\subsection{Relationships between investigated traits}

Relationships between the properties of all genotypes are given in Table 6. Positive relationships was found between yield, plant height and spike grain weight. In addition, positive and strong relationships was found between the flag leaf chlorophyll content of milk development stage and the flag leaf chlorophyll content in heading stage and flag leaf chlorophyll content of anthesis stage. It was determined that physiological characteristics was generally related to each other and there was no relationship among physiological characteristics and yield and yield components examined in the study. It was concluded that it would not be easy to select genotypes according to a defined traits. The fact that spike grain weight is related to yield shows that genotype selection should be taken into consideration. The negative relationship between plant height and canopy temperature indicates that the tall genotypes has more cooling mechanism. The correlation between plant height and yield results in parallel with the results of previous studies (Aykut et al., 2005; Bilgin \& Korkut, 2005). The positive effect of spike grain weight on yield was determined in different study results (Dokuyucu et al. 1997; Bilgin and Korkut 2005). Therefore, in the selection of varieties with good yield characteristics, varieties with high spike grain weight and spike grain number should be preferred.

\section{Conclusions}

In this study, Augmented design was used successfully in comparing many lines with each other. This designs will enable the breeder to perform a valid statistical analysis despite the large number of new selections. 
Table 6. Correlation parameters and significance levels of 120 advanced durum wheat lines examined

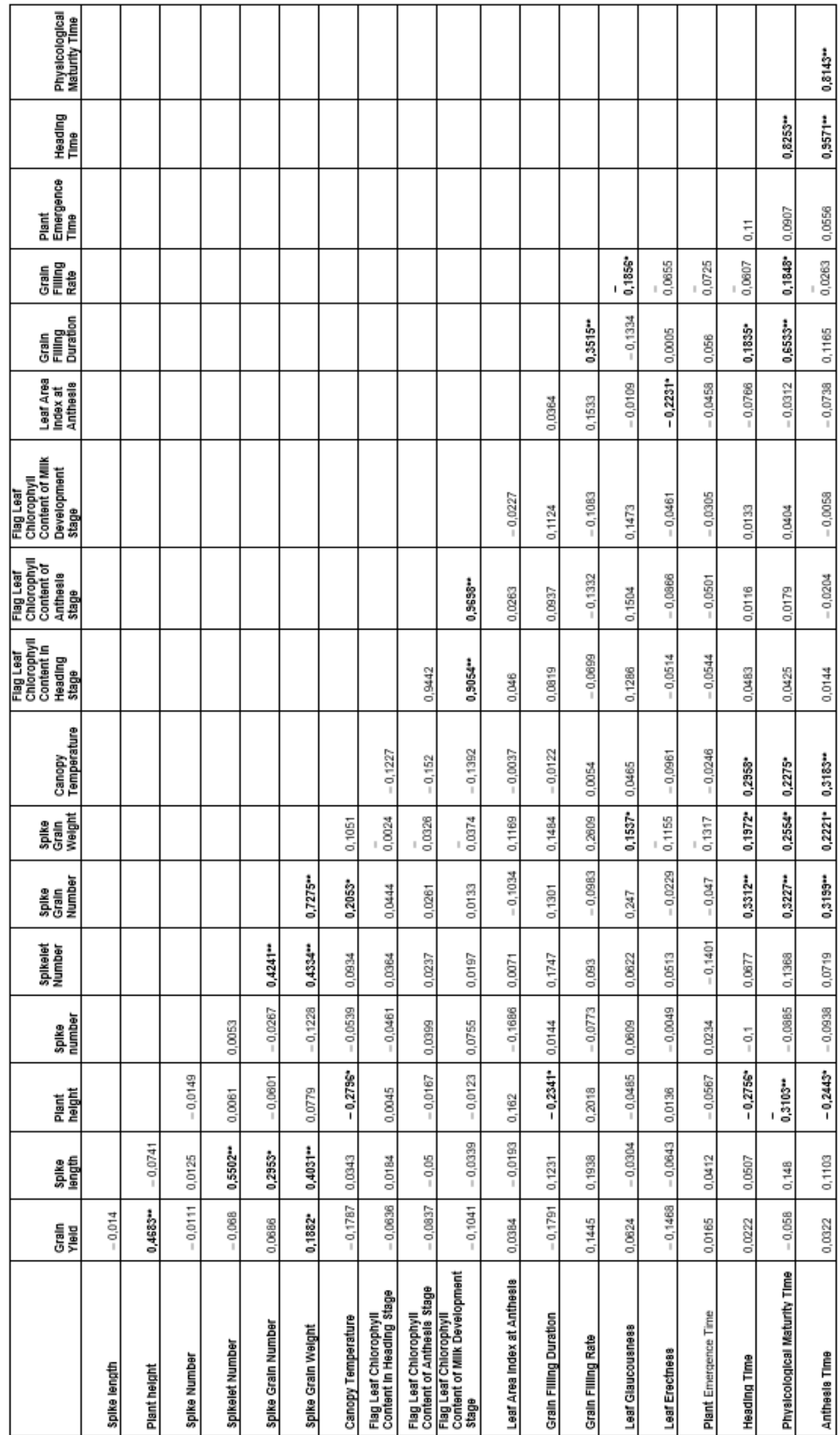


In this study, the lines of 5, 50, 85, 34 and 94 in terms of physiological properties; 114, 42 and 52 lines in terms of phenological characteristics; 92, 42, 41 and 18 lines in terms of morphological features and in terms of yield and yield components 31, 5, 16 and 18 lines was found to have superiority above control varieties. As a result of the research, it was concluded that selection of varieties can be misleading by considering only single traits. In recent years, due to the effect of global warming, adaptation to changing climatic conditions has made it difficult to breed new varieties. It strengthened the idea that only yield based choices was inadequate in developing new varieties. According to the results of the research, it was observed that the high yielding lines did not show the same good results in terms of the other properties examined. As a result of the research, 13 lines $(5,16,18,3,34,41,42,50,52,85,92,94$ and 114) which showed superior features than the control varieties was determined.

\section{References}

ABD EL Samie \& Acer, S. (2004). Effects of Different Irrigation Times with Nitrogen Doses on Yield and Quality Specially in Some Durum Wheat Varieties. Institute of Natural and Applied Sciences University of Ankara, Ph.D. Thesis, Ankara.

Aktan S. \& Siirt S. \& Şenel H. \& Keklikçi Z. \& Nergiz N. (2003). Research on Growing Technique in Wheat Varieties in Dicle - 74 (Triticum durum L) Penjoma - 62 and Bezostaya - 1 (Triticum aestivum L) in Southeastern Anatolia. Agricultural Research Abstracts. Southeastern Anatolia Agricultural Research Institute. 201 p.

Aykut, F. \& Yüce, S. \& Demir, İ. \& Akçalı Can, R. R. \& Furan, M. A. (2005). Performance of bread wheat varieties and lines under Bornova conditions. Turkey VI. Field Crops Congress, 5 - 9 September 2005, Antalya Volume I, 89 - 93.

Bilgin, O. and Korkut, K.Z. (2005). Determination of some bread quality and grain yield charactersin bread wheat (Triticum aestivum L.). International Journal Of Agriculture \& Biology, 7(1): 125 128.

Bouyoucos, G.J. (1951). A Recalibration of The Hydrometer For Making Mecanical Analysis of Soil. Agro. J.,(43): $434-438$.

Demir, İ. \& Yüce, S. \& Tosun, M. \& Sekin, Y. \& Köse, E. \& Sever, C. (1999). A Study on Determination of Some Quality Characteristics of Advanced Bread Wheat Lines. Turkey III. Field Crops Congress, 15 - 18 November, 1999, Adana, p. 354 - 359.

Dokuyucu, T. \& Akkaya, A. \& Nacar, A. \& İspir, B. (1997). Investigation of Yield and Yield Components and Phenological Properties of Some Bread Wheats in Kahramanmaraş Ecological Conditions, Turkey II. Field Crops Congress, 22 - 25 September 1997, Samsun, p. 16 - 20.

Erkul, A. and Ünay, A. (2009). Inheritance of Quantitative Characters in Three Wheat Crosses (Triticum aestivum L.) I. Yield and Yield Components. Journal of Agricultural Faculty of Adnan Menderes University, 6(2): 63 - 68.

Fasoulas A. C. (1973). A new approach to breeding superior yielding varieties. Dept. Gen. Plant Breeding. Aristotelian University of Thessaloniki, Greece: Publ. 6, pp.55.

Federer, W. T. (1961). Augmented designs with one-way elimination of heterogeneity. Biometrics, vol. 17, pp. 447-473.

Federer, W. T. \& Ragavarao D. (1975).On augmented designs. Biometrics,vol. 31, pp. 29-35.

Fehr, W. R. (1987). Principles of cultivar development. Vol. I. Theory and Techniques. Macmillan Publishing Company, N York, USA: pp.536.

Gangul1, et al. (1997). Wildlife and Fisheries Management. Journal of Range Management, 72(5): $494-497$. 
Hadjichristodoulou, A. (1982). The Effect of Annual Precipation and Its Distribution on Grain Yield of dryland Cereals. The Journal of Agricultural Science, 99(2): 261 - 270.

IGC, (2017). International Grains Council, . Retrieved June 22, 2019 from https://www.igc.int/en/default.aspx

Kahraman, T. (2006). The determination of the effects of different planting time and nitrogen fertilizer applications on grain filling duration and grain filling rate with on yield and quality components in some bread wheat varieties . Trakya University Graduate School of Natural and Applied Science Department of Field Crops, Ph. D. Thesis, Tekirdağ.

Kahraman, T. \& Avc1, R. \& Öztürk, İ. (2008). Determination of Grain Yield and Some Quality Characteristics of Some Bread Wheat Lines Developed as a result of Breeding Studies. National Grain Symposium, 2 - 5 June, Volume I, Konya, p.732 - 737.

Kahrıman, F. (2007). Determınatıon of Quality and Yield Levels of Some Bread Wheat Varieties . Canakkale Onsekiz Mart University, Graduate School Of Natural and Applied Science, Master Thesis, Canakkale.

Karaman, M. (2013). Investigation of some physiological and morphological parameters in some bread wheat (Triticum aestivum L.) varieties. Institute of Natural and Applied Sciences University of Dicle, Master Thesis. Diyarbakir.

Kendal, E. (2008). Effect of different levels of zinc fertilization (ZnSO4) on yield and yield components and quality traits of some durum wheat varieties (Triticum turgidum Var. Durum L.) in the southeastern Anatolian region conditions. Institute of Natural and Applied Sciences University of Cukurova, Master Thesis. Adana.

Kendal E. et al. (2012). Comparison of some local and Italy Durum Wheat Varieties in Terms of yield and Quality Parameters in irrigation conditions of Diyarbakir and Adiyaman. Journal of Agricultural Faculty of Uludag University, 26 (2): 1 - 14.

Koç, M. and Barutcular, C. (2000). The relationship between leaf area index and yield during flowering period in wheat under Çukurova conditions. Turkish Journal of Agriculture and Forestry, 24(2): $585-593$.

Kün, E. (1988). Cool Climate Cereals. Ankara University Faculty of Agriculture Publications No: 1032, Textbook: 299, Ankara, 322p.

Lawless, H. \& Schlake, S. \& Smythe, J. \& Lim, J. \& Yang, H. \& Chapman, K. (2004). Metallic Taste and Retronasal Smell. Chemical Senses, 29(4): $25-33$.

Mut, Z. et al. (2005). Investigation of Yield and Primary Quality Characteristics of Some Bread Wheat (Triticum aestivum L.) Genotypes. J. of Fac. of Agric., OMU, 2007,22(2):193 - 201.

Neukam, D. et al. (2015). Modelling wheat stomatal resistance in hourly time steps from micrometeorological variables and soil water status. J. Agron. Crop Sci. [Google Scholar].

Özdemir, S. (2011). Determination of the optimum sowing rates of wheat varieties sown in different locations. Osmangazi University, Institute of Natural and Applied Sciences, Master Thesis, Eskişehir.

Özer, M. S. (1998). Determination of some characteristics of bran added breads and improvement of their qualities Institute of Natural and Applied Sciences University of Cukurova, Ph.D. Thesis, Adana.

Papadakis I. S. (1935). The pocket method of varieties experiments. Scientific Bulletin No. 21, Institute of Plant Breeding, Salonika, Greece. 
Petersen R. G. (1985). Augmented designs for preliminary yield trials (revised). Rachis,vol. 4,pp. 27 -32 .

Reynolds, M. P. \& Delgado, M. I. \& Gutierrez - Rodrıguez, M. \& Largue, A. (2000). Photosynthesis of Wheat in a Warm, Irrigated Environment - I: Genetic Diversity and Crop Productivity. Field Crops Research, 66(8): $37-50$.

Royo, C. \& Garc'ia del Moral, L. F. \& Slafer, G. \& Nachit, M. N. \& Araus, J. L. (2005). Selection tools for improving yield-associated physiological traits. In: Durum Wheat Breeding: Current Approaches and Future Strategies. pp. 563-598. Haworth Press, New York.

Sade, B. \& Topal, A. \& Soylu, S. (2000). Determination of durum wheat varieties that can be grown in Konya irrigation conditions. Problems and Solutions of Cereal Agriculture in Central Anatolia. Symposium, 91-96, 8-11 June, Konya.

Sakin, M. A. et al. (2004). Determining the Yield, Yield Components and Quality Properties of Some Durum Wheat Genotypes in Tokat - Kazova Conditions. Journal of Agricultural Sciences, 10(4): $481-489$.

Tekdal S. (2012). Investigate of Physiological and Morphological Parameters That Can Be Utilization in the Determination of Heat Stress Tolerance in Durum Wheats (Triticum Durum Desf.). Master Thesis, Department of Field Crops Institute of Natural and Applied Sciences University of Dicle.

Toncin, R. (2004). The Influence of Seeding Density and Environmental Factors on Grain Quality of Main Stems and Tillers of Wheat in South Australia. A Thesis Submitted for the Degree of Doctor of Philosophy School of Earth and Environmental Sciences the University of Adelaide, 207p.

Turan, İ. (2008). Determining of yield and yield traits of some wheat, barley and triticale varieties in Kahramanmaraş conditions. Unıversıty of Kahramanmaraş Sütçü İmam, Instıtute of Natural and Applied Sciences, Master Thesis, Kahramanmaraş.

Turkish Statistical Institute, (2018). Crop Production Statistics. Retrieved June 22, 2019 from https://biruni.tuik.gov.tr/medas/?kn=92\&locale=tr

Valerio I.P, et al. (2009). Seeding density in wheat genotypes as a function of tillering potential. Sci. Agric. 66 (1): 28 - 39. http://dx.doi.org/10.1590/S0103 - 90162009000100004

Yıldırım, M. et al. (1996). Factor Analysis of Yield and Related Traits in Bread Wheat. Turkey Journal of Field Crops, 1(2): $11-15$.

Yildirım, M. et al. (2018). Correlation Analysis of LAİ, SPAD, NDVI, Ct with Grain Yield and Quality Traits of Some Bread Wheat Genotypes at Heading Stages. Anadolu International Multidisciplinary Studies Congress, Congress full text book, 28 - 29 December 2018.

Yürür, N. \& Tosun, O. \& Eser, D. \& Geçit, H. H. (1981). Relationship Between Main Stem Yield and Some Characters in Wheat. Ankara University Faculty of Agriculture Publications. 755 Scientific Research and Studies: 433. Ankara. F19 p. 